ISSN 2519-2523 (print)

Chornomors'ka mynuvshyna. - 2020. - No.15

DOI: $10.18524 / 2519-2523.2020 .15 .218686$

УДК 929Комаров:82-6 “189/192”

\title{
LETTERS TO ODESA RESIDENT MYKHAILO KOMAROV FROM ST. PETERSBURG, MOSCOW, KUBAN AND OTHER REGIONS OF THE RUSSIAN EMPIRE OUTSIDE UKRAINE, AS A MANIFESTATION OF THE CONSOLIDATION OF THE NATIONAL MOVEMENT AT THE TURN OF THE XIX AND XX CENTURIES
}

\author{
Taras Honcharuk \\ ORCID: https://orcid.org/0000-0002-0119-0227 \\ DSc (History), Professor \\ Odessa I.I.Mechnikov National University \\ 2, Dvoryanska Str., Odessa, 65082, Ukraine \\ tarasiy2004@ukr.net
}

Letters to the Odesa bibliographer, writer and public figure Mykhailo Komarov (1844-1913) from the collection of manuscript fund of the Odessa National Scientific Library are examined in the publication. The letters written by the authors from the lands outside Ukraine within its modern borders, but within the territory of the former Russian Empire, are analyzed. In particular, letters from St. Petersburg and Moscow, including letters of such famous scientists and cultural figures as D. Yavornytskyi, D. Mordovets, O. Lototskyi, P.Stebnytskyi and others are examined. Letters to M. Komarov from the Kuban, in particular from Ya. Bihdai, M. Dykariv, V. Skyda and others; from the Voronezh province from B.Poznanskyi; from Ryazan province from H.Machtet, from Moldova from K.Shram; from Siberia from A. Fisun and others are also analyzed. It is emphasized that the cooperation in the exchange of printed materials and the promotion of Ukrainian-language publications and Ukrainian studies publications in various regions of the country, despite censorship prohibitions were the important factors for communication between Ukrainian cultural figures at the turn of the XIX-th and XX-th centuries. The article contains the texts of fourteen letters to M. Komarov from thirteen persons from the different regions of the empire. The texts of these letters indicate that one of the leading topics in the publishing and other spheres of the cultural national Ukrainian movement in the Russian Empire of this period were the study and the popularization of the history of the Ukrainian Cossacks and its leaders. In the investigation the author makes the conclusion that it is necessary to publish as soon as possible, with appropriate comments, of all letters to $M$. Komarov from the manuscript fund of the Odessa National Scientific Library - about 1000 shits - to provide to wider range of researchers opportunities for comprehensive analysis of their content.

Key words: M. Komarov, Odesa Hromada, Odesa Prosvita.

Тарас Гончарук

ORCID: https://orcid.org/0000-0002-0119-0227

Доктор історичних наук, професор

Одеський національний університет

імені І.І. Мечникова

Вул. Дворянська, 2, Одеса, 65082, Україна

tarasiy2004@ukr.net 


\section{ЛИСТИ ДО ОДЕСИТА МИХАЙЛА КОМАРОВА 3 ПЕТЕРБУРГУ, МОСКВИ, КУБАНІ ТА ІНШИХ РЕГІОНІВ РОСІЙСЬКОЇ ІМПЕРІЇ ПОЗА МЕЖАМИ УКРАЇНИ, ЯК ПРОЯВ КОНСОЛІДАЦЇ̈ НАЦІОНАЛЬНОГО РУХУ НА ЗЛАМІ XIX TA XX CT.}

В публікації розглядаються листи до одеського бібліографа, письменника та громадського діяча Михайла Комарова (1844 - 1913 рр.) зі збірки, щсо міститься у рукописному фонді Одеської національної наукової бібліотеки. Аналізуються ті листи, щчо були написані авторами зі земель поза межами Украӥни в ї̈ сучасних кордонах, але в межах теренів тодішньої Російської імперії. Зокрема, розглядаються листи написані з Петербургу та Москви. В тому числі такими відомими вченими та культурними діячами, як Д. Яворницький, Д. Мордовечь, О. Лоточький, П. Стебницький та ін. Розглядаються листи написані до М. Комарова з теренів Кубані, зокрема, Я. Бігдая, М. Дикаріва, В. Скидана та ін. Також листи написані авторами з Воронезької губернї - Б.Познанським, Рязанської губернії - Г. Мачтетом, Молдови - К. Шрамом, Сибіру - А. Фісуном та ін. Наголошується, що важливими факторами для комунікації між українськими культурними діячами на межі ХІХ та XX cm. були співпрачя щчодо обміну друкованою продукиією та сприянню виходу в світ україномовних та українознавчих видань в різних регіонах країни попри цензурні заборони. До статті подано тексти чотирнадияти листів до М. Комарова від тринадцяти діячів 3 різних регіонів імперії. Тексти вказаних листів свідчать, щчо одну з провідних тем у видавничій та інших сферах культурницького національного украӥнського руху в Російській імперії вказаного періоду займало вивчення та популяризачія історії украӥнського козацтва та постатей його провідників.

В розвідиі робиться висновок про необхідність якнайскорішої публікаиії, з відповідними коментарями, усього масиву листів до М. Комарова з рукописного фонду ОННБ - близько 1000 аркушів - для надання ширшому колу дослідників можливостей комплексного та всебічного аналізу їхнього змісту.

Ключові слова: М.Комаров, Одеська «громада», Одеська «Просвіта».

Збірка листів до визначного українського бібліографа, письменника та громадського діяча Михайла Комарова (1844 - 1913 рр.), що зберігається у рукописному фонді Одеської національної наукової бібліотеки, привертала та продовжує привертати інтерес істориків та літературознавців. Їй, в тій чи іншій мірі, вже присвячено десятки наукових публікацій (за браком місця ми тут їх згадувати не будемо) й зацікавленість дослідників вказаною збіркою не зменшується. Це не дивно, адже в ній вміщені тексти листів до М. Комарова від двохсот осіб серед яких були як визначні українські діячи кінця XIX - початку XX ст. (I. Франко, М. Грушевський, М. Міхновський, Є. Чикаленко та ін.), так і постаті маловідомі або практично невідомі дослідникам минулого. Тексти листів були передруковані свого часу машинкою та розташовані за абеткою в залежності від прізвищ авторів (за цим же принципом розташовані тексти кількох листів зі збірки в кінці цієї публікації).

Окрім іншого, в збірці листів до М. Комарова вражає географія місця їхнього написання. В ній представлені листи з десятків населених пунктів Наддніпрянської та Західної України, країн Свропи, а також теренів Російської імперії поза межами України. Останні ми коротко розглянемо в цій публікації за географічним принципом.

Низка листів до М. Комарова було надіслано зі «столиць» імперії - Петербургу та Москви. Зокрема, листи 1883-1894 рр. від українського громадського діяча та археолога Вільгема Беренштама, який в цей час жив та викладав в гімназіях Петербургу. В листах подавалася інформація про діяльність Д. Багалія, стосунки М. Костомарова, О. Потебні, В Антоновича на науково-видавничій ниві й про 
цензурні утиски проти видання «Зорі» та проти українського культурництва загалом [3, арк. 23-29]. У збірці присутні листи від українського поета, перекладача та видавця Кесаря (Цезяря) Білиловського надіслані з Петербургу та пізніше - 3 Мітави. Один 3 останніх наводимо у додатках (див. додаток 3). В ньому, між іншим, йдеться про книжку М. Комарова «Оповідання про Антона Головатого та початок Чорноморського козацького війська» петербурзького видання 1901 р. Питання підготовки цього видання до друку розглядалися в листуванні М. Комарова 3 українським письменником, науковцем та громадським діячом Олександром Лотоцьким, який на початку XX ст. працював та мешкав у Петербурзі (див. додатки 6 та 7). В листах згадується, що обкладинку для цієї книги робив «д. Ждаха» (див. додаток 7), вочевидь, мається на увазі «д.[обродій] Ждаха» - видатний український художник та графік Амвросій Ждаха. У збірці також вміщено тексти широкого масиву листів до М.Комарова 3 Петербургу 1898 - 1910 рр. українського громадського та культурного діяча Петра Стебницького переважно про видання та поширення української друкованої продукції, проблеми 3 цензурою та ін. Нижче наведено текст одного з них (чи не найменшого за обсягом), в якому також йдеться й про підготовку до видання вищезгаданої книги М. Комарова (див. додаток 11). Низку листів 3 Кисловодську та Петербургу надіслав М. Комарову український та російський письменник Данило Мордовець [3, арк. 134-142]. У додатках вміщено текст першого з цих листів (див. додаток 9), де, між іншим, згадується журнал «По суше и морю» - своєрідний друкований орган одеської української «громади». В збірці також вміщені інші листи до М. Комарова 3 Петербургу, зокрема, П. Солоділова (між ними, цікавий лист 1906 р. про перспективи українських видань, та необхідність публікації перекладів світової класики на українську мову [4, арк. 76]), П. Гейцига, що хотів отримати портрет М. Комарова для своєї колекції портретів визначних діячів імперії [1, арк. 46-47] та ін.

Серед листів збірки М. Комарова отриманих одеським діячом з Москви варто згадати надісланий ветеринаром Сергієм Вагановим (див. додаток 4) та істориком Дмитром Яворницьким (див. додаток 14). 3 останнього видно 3 якою повагою ставився до точки зору М. Комарова визначний дослідник минулого запорозького козацтва (у збірці представлено ще кілька листів до М. Комарова від Д. Яворницького) [6, арк. 45-49].

Низка листів були надіслані до М. Комарова $з$ теренів компактного проживання українців поза межами України: з Кубані, воронезької Слобожанщини, Донщини. Це, зокрема, лист від відомого кубанського збирача українського фольклору Якима Бігдая, де він повідомляє про свої успіхи в обходженні цензури (дивись додаток 2), листи (з Воронежу та Кубані [2, арк. 75-77]) від відомого фольклориста Митрофана Дикаріва (один 3 них подано у додатку 5), листи відомого українського кубанського діяча Володимира Скидана щодо видань 3 козацької історії та зображень козацьких отаманів на пам'ятнику Катерині II тощо [4, арк. 61-71] (один з них подано у додатку 10), лист кубанського бібліографа В. Шамрая (див. додаток 12). Також у збірці вміщені тексти листів відомого українського діяча Бориса Познанського 1896 р. 3 Острогозька («Острогожське», як писав сам Познанський) Воронезької губернії [4, арк. 18-25], в яких розглядалися перспективи видань україномовної продукції й ставлення до неї місцевої «еліти» (наприклад, Б. Познанський писав: «О це недавно був у мене князь Урусов - адвокат... побачив Киівську Старину i каже: Сепарастический журнал получаете») [4, арк. 18-25]. Збирач українського фольклору 
3 Донщини Терентій Безшлях звертався до М. Комарова $з$ проханням надіслати томи його російсько-українського словника (див. додаток 1).

Присутній у збірці й лист відомого українського та російського письменника та революціонера Григорія Мачтета з Рязанської губернії. Показово, що в ньому теж йдеться про одеське українофільське видання «По морю и суше» (див. додаток 8). Деякі листи, тексти яких вміщені у збірці, були написані М. Комарову з Молдови. Зокрема, це листи українських акторів, які гастролювали у Кишиніві та досить патріотичний лист К. Шрама (Костя Іващенко), що вміщений у додатках (див. додаток 13). Є серед текстів листів збірки М. Комарова й ті, що були написані в далекому Уралі та Сибіру. Наприклад, листи Михайла Боровського доля якого занесла з бессарабського Болграду, аж до уральського Ірбіту [2, арк. 78-81]. Або листи скульптора Г. Фішеля 3 Томську, який вирішив взяти участь у конкурсі проектів пам'ятника Т.Шевченка (якого скульптор називав не інакше, як «генальным певцом Украйны») і якому М. Комаров надсилав необхідні друковані матеріали щодо життя та творчості поета [5, арк 49-52]. Також у збірці є короткий текст листа арештанта Антона Фісуна від 10 жовтня 1910 р. він писав М. Комарову: «Прохав книжок прохав і грошей і ніхто нічого не дав тепер звертаюся до Вас прошу надіслати книжок і запомогу грішми алчущій і жаждущій як на те так і на друге. Перше всього Кобзаря послідне видання...». Адреса цього листа: «Село Александровское Иркутской губ. Центральная Каторжная Тюрьма арестанту Антону Фисуну» [5, арк 48].

Вміщені у збірці з фондів ОННБ листи до М. Комарова зайвий раз засвідчують наявність процесів консолідації діячів українського національного руху на зламі XIX та $\mathrm{XX}$ ст. не лише у межах українських земель, але й поза ними. Одеські діячі відігравали в цьому процесі одну з провідних ролей. Листи до М. Комарова зі збірки ОННБ, що нараховують понад тисячу аркушів надрукованого тесту, попри наявність десятків наукових публікацій ним присвячених, потребують подальшого наукового вивчення. А передусім вони потребують публікації, на яку вони вже чекають понад сто років.

Документи:

Документ №1. Лист Т. Безиляха. 1902 р. Ростов-на-Дону.

«Ростов н/д 8 декабря 1902 г.

Выбачайте, що я прозвыща не знаю Вашого ймення, хоч и соромно украинским читатчам не знати его. Хочу я Вас ось про що прохаты. Е в мене частына «РосійськоУкраинського словаря» лыш вид А до К - те що «Зоря» змогла выслати в Россію покы небула заборонена. А бачыв я у пана Жарка у Мариуполи повный такый словарь - значить сей словарь писля «Зори» був допущен в Россію, але я того не знав. Так оце я - до Вас, як о чоловика, которому можлыво бильш ниж усякому другому: чи не зможете Вы дистать для мене повный такий словарь, хоч почынаючи вид К, хоч вид А, не вважаючи на те, що у мене е до К. Запевне у Вас, у Одесси, е зайвий, то будьте ласкави, звистить мене якым робом можете /коли можете/ выслать его мени и яка йому цина. А як що нема, то чы не можете дистати з-за кордону - я чув, що Вам те можлыво. Выбачайте за турботу, та коли б я мав змогу сам прыдбав его, а то не знаю навить куды кынутись и де его пытати. Мени про Вас яко украинского передовыка и либерала, казав видомый Вам Антин Фысун /Бог его зна де вин тепер повертаеться/, то я - осмилывся обернутись оце до Вас 3 надіею, що Вы в такій нужди поможете мени. Ще раз прошу: выбачайте.

Адрес: Ростов н/д. страховое общество «Россия» Т.Т.Безшляху.

Щыро прыхыльный до Вас Т.Безшлях» 


\section{Документ №2. Лист Я. Бігдая. 1896 р. Кубань.}

«Якось Ви мені писали про ту гемонську цензуру, та так налякали, що я думав - думав, а далі й рішив: - «хай вона собі сказиться». Ходить біля неі, тіко гріха наберешся, лучше не показуватися, так і зробив, як ви сами бачете із книжок, котрі Вам по приязні презентую. Як воно все вийшло побачете із книжок. Цензура не полізе, бо це «наукове видання», до 2-му тому, Воно ж к тому «войскове». Як був наш отаман у царя на коронаціі, то царь його спитав: «ащо будуть у вас які небудь видання»? Отаман сказав - «постораімося». - От ми і постарались, а тепер один экземпляр і посилаем царю. Як що от царя буде «яке слово», то нужно буде понести його так, щоб усіх ваших цензорів аж у носі закрутило. Предполагалось, i внесено в сміту, котру утвердив военний министр, що відання це буде войскове, т.е. на войскові гроші, но... грошей нехватило. Упустить такого для украінськоі мови случая, нехотілось і я іздав на свій кошт. На Кубані вони пішли здорово, но нужно помочі і од Вас, так как, я думаю поскоріше випустить і іще випуска три чорноморськіх пісень, а потім, під цією же ученою оболочкою «матеріали» й перейти до пословиц, казок, анектодів і творів.

Як що прівітаете цей збірник, то діло піде, а ні - мабуть духу не хвате. Лінейські поміщени во 1-х для сравнения, а во 2-х, щоб непривьязались за «разрешаю печатать», так як половина кубанців - лінейці, а тому же і празновали юбилей, по хоперскому полку.

Маю надію, що ви і пером і слововм поможете цему начатку. Поставить це діло, т.е. мій широкий заголовок - «матерьяли к ізученію Кубанскої області» треба поскоріше, бо наш, дуже щірий отаман, я йому і посвятив, може перевестись, а тоді - начинай знову. Я послав книжки в Вороніж вашому братові, Харьков - Багалію, Київ - Антоновичу і Олени Косич. Як що ви переписуетесь 3 ними, то замовте і од себе добре слово. Здорово лаятся за корректуру не треба, бо печаталось на курьерскіх; потім все це справитця.

Пішіть стіко экземплярів нужно буде для Одеси то по адресу прямо вишлють із Москви от Гроссе, щоб не пересилатця сюди й туди.

Жду от Вас ласки і привіта. Як що піддержете заворушившуся Кубань, то й для Вас буде лучше.

Може ще кому із наших пріязників послать книжки? Напишіть.

А Бігдай. 25/IX - 1896»

\section{Документ №3. Лист Ц. Білиловського. 1901 р. Мітава.}

Вельми шановний Михайло Хведоровичу.

«Митава 29/IV 1901 р.

Велике Вам спасибі за Ваш гарний подарунок - книжку про Головатого. Звеселив мене не так ваш подарунок, як памьять Ваша об мені. От вже 3-ій рік минає, як я силю тута межі німці та латишів сам-самотний, забутий від усіх. Вперве Ви оце згадали про мене і любого гостинця прислали. Вельми мині жо вподоби Ваше оповідання. Написано просто, цікаво і легко. Немає ні викрутасів, ні вигадок, ані словокручених вистругив. Отак самісенько оповідав би і Омелько і Панас і Овсій і другі дядьки або діди у селі.

А ще й добре і гаразд зробили, що именно про Головатого написали. Згадали людім про часи славетні, про діі незабутні. Змалювали велику і дуже зрушливу трагедію - смерть, нагальну смерть Единих того часу на світі лицарів. Вичитав і довго-довго думав сумуючи, $\mathrm{i}$ сумував, думаючи. Що за чудовий и вдячний матерьял за для драми чи трагедіi. Одна постать Головатого чого коштує. Які сцени напрошуються. От де за для творчості простір безкраій, а за утвір хороший слава в народі.

Що-ж ище, дорогий Михайло Хведоровичу, Вам сказать? Нічого хорошого, нічого веселого! Велике горе спіткало мене. Сього лютого поховав я мою квітку-доньку, котру Ви бачили у мого брата ув Одесі. А з нею в купі двох ще синів Юрка і Миколу /Юрка знає Олексій/ - всіх від скарлатини, що вніс мені у хату один хворий хлопчик-латиш.

Писати нічогісенько не пишу. Часто набігають на мене думки, часто сумую, задріжить i загуде у серці якась ледаща струна, здається, викричав-би на весь світ жалощі моі, - i тільки похитає головою, махну рукою і знов заціпну, знов німий! Мині рідних людей треба, рідної 
мови, рідного повітру, рідноі землі - знов би сили набравсь, зкинув-би кригу з себе і пішовби пінявою хвилею, покотився-би, поринув-би, миючи і низини 3 калиновими кущами i скелисті береги з крутими бескидами.

Ще раз спасибі, Цілую Вас здалека так саме, як і в Одесі цілував.

Також і Олеся.

Ваш К.Білиловський.»

ОННБ. РКП 28/1. - Арк 21, $29-30,53-54$.

\section{Документ №4. Лист С. Ваганова. 1900 р. Москва.}

Щиро поважаемий Михайло Хведорович.

«17.XII. 900 г.

Ви мабуть трохи здивуетесь одібравши цей лист, але я николи не викидав Вас 3 свого серця, з своіх думок, а від того зад для мене не було б незвичайним, як би я одібрав Вас лист, хоч проминуло не мало часу, як я й перестав читати Ваші до мене листи. Не листи звязують людей, а те - чим іх серце сповнено: на листі ж вони добром до рідної украіни. Обертаюсь до Вас от $з$ яким ділом. Скажіть на милість - чи Ваша цензура розріша до печаті на нашій мові наукові брошури. Мені оце вчора повернули з Питра рукопись и С.П-скій цензур К-т розішив дрюкувати мою брошуру «Розмова про Сухоти рогатоі худоби. Яка ця болість і як від неі боронитись». Не знаю, як і де іі дрюкувати. Кийане казали в осени, що вони надрюкують, а проте хто его зна. Може Ви знаете, як це діло зробити і як кийане не зможуть, то тоді згожусь на Вашу пораду. Як що ця праця сподобиться Вам, то маю надію написати про «Сказ, телій, сап и др. хвороби. Я тут познаемився з п. Яворницким, людина страшено щира, поіхав оце в Катеринодар читати про своіх запорожців. Написав він де-що про Ваш словарь : я ему радів одіслати до Вас и те що написав і ті слова /900/ котріх не долічує він з свого боку в вашім словарі. Він з цією думкою згодився, мабуть так і зробе. Словарь Ваш він ліче кращою настольною книжкою.

Будьте ласкаві пришліть мені Ваш словарь Руссько-Укр. наложним платежем по ардес: Москва. М.Бронная, д. Гирш, кв. №71, буду щиро дякувати, бо в наших московских книгарнях словаря Вашего нема, а на юг не приходилось зіздить. Я чув від братка, що Ваша Віруся вийшла заміж - щасти-ж ій доля. Як же ви поживаете, ваше здоровьячко. За кутею, котра у нас завжди робиться по звичаю любоі старини, ми згадаемо Вас і тепер, як згадуемо, що року, бо кажу - Вас николі не забуваю. Всім Вашим щире бажанье здоровья, а 3 новим роком ще кращого, веселого житья!

Обнімаю Вас и щирими вустами цілую - кріпко, кріпко, щоб нихто Вас так кріпко не поцілував на новий рік, як щиро до Вас прихільний.

С. Ваганов».

\section{Документ №5. Лист М. Дикаріва. 1897 р. Катеринодар.}

Високоповажний Добродію Михайле Федоровичу!

«Катеринодар 2.II.97.

Заходившись писати Вам листа після довгого мовчання, я не знаю, с чого й почати. Почну с патрета Т.Г.Шевченка, що разом з сим засилаю Вам. Се вже копія з копії, і до того через лад блідної: тим-то патрет вийшов невдатним. Первовзір був знайдений д.Волошиним, тепер совітником Обласного Правленія, під час його перебування в Київськім університеті у одного $з$ «старих громадян».

Про свої роботи подам от-що. Зараз в «Этногр. Обозр» друкується моя велика розправа п.з. «По поводу народных толков 1896 г. о царских загацках». Се загацки х приводу коронації про відберання від панів землі на користь селянам. Додатки до сеї розправи будуть етнографічні матеріали, зібрані мною перевагом на Чорноморіи. Я маю починити де-які виводи на підставі сих матеріалів і все надрукувати в «Етнологичнім Збірнику» Наук. Тов. ім. Шевч. п.з. «Народна поголоска з поводу коронації 1896 р.». 
Вам мабуть вже відомо, що в т. II «Етногр. Збірн.» надруковані мої «Чорноморські казки й анекдоти».

Далі стоїть на черзі друкованннє моїх вороніжських етнологічних матеріалів, котрих у мене назбіралось мабуть аркушів на 1000 писаних. Багато буде мороки над впорядкуванням їx. Думаю почати виданнє з народного акушерства і родин з хрестинами, а тоді вже перейду до дитячого життя. Всі от сі матеріали маю друковати в Галиччині.

Тепер збіраються мані відомості про народну гутірку з поводу одноденної статістичної переписи. Словом сказавши, я, мовляв, стараюсь бути в курсі сучасного народного життя.

Сей рік звичаєм попередніх років роковини Т.Г.Шевченка будуть святкуватися тут роздачою бідним міщанам його «Кобзаря». Перший рік було роздано 10 примірників, придбаних моїм власним коштом, торік 15 примірників - на зібрані гроші, і сей рік на такі-ж гроші буде роздано 24 примірники. Такий спосіб святкування я вважаю найбільш відповідним істоіті свята, ніж визволяннє шинкарів по панських шинках.

На-сам-кінець скажу Вам, що ось уже два роки як ни покидає мене клятий чорноморський «корчій». Багато я витратив грошей на ліки і все марно. Літом того року я на місяць їзди до Новомосковського, і там тільки чув полегкість. Вже 3 самого виїзду 3 Катеринодару наче як одрізало, і так було, поки я не звернувсь знов сюди. За два роки хвороби з мене став такий робітник, як батіг 3 клоччя, цілі тижні і місяці проходять у мене без ніякої роботи. Так от же я поклав мерщій куди [...] втікати з гнилої Кубані, аби тільки на Україну. Том удаюся Вас з уклінною просьбою: коли почуєте про яку підхожу службу, будьте ласкаві повідомте мене.

Не знаючи жодної одеської книгарні потурбую Вас ще одною уклінною прозьбою: будьте ласкаві надіщліть мені 3 наложеною: «Матеріали по етнографії нововроссійського края» В.Н.Ястребова.

3 глибоким поваженнєм до Вас М.Дикарів» (II арк 78 - 79)

ОННБ. РКП 28/2. - Арк. 2-3, $78-79$.

\section{Документ №6. Лист О. Лотоцького. 1901 р. С.-Петербург.}

«Високоповажний Михайло Федоровичу.

Дозволяю собі турбувати Вас в справі заповіту О.Я.Кониського, мені він заповів права літературної власності на всі свої твори - друковані і недруковані, а разом постановив мене душеприкащиком що-до свого майна, яке він заповів здебільшого закордонним українським інституціям. Що до першого заповіту - про літературну власність, то річ безперечна, що він буде затверджений. Але другий заповіт - що-до маєтку, то родина небіщика захожується его оспорювати. На ведення судової справи потрібні кошти, а в мене на жаль їх немає. От я і дозволяю звернутися 3 сією справою до Вас на той случай, коли не небіщикові О.Я. Кониському належить що одержати за видання его творів - українських та «жизнь укр. поэта Т.Г.Шевченка». Коли справді належить ему що небудь, то я просив би дати мені $з$ того яку дещицю на ведення справи - рублів 100- 150. Коли одержу от Вас відповіді, то перешлю Вам нотаріальну копію заповіту, який може бути потрібним для «Ю.-Р. Общества печатного дела».

Прошу і сподіваюся на скору Вашу відповідь, - бо думаю скористуватись масляницею та поіхать в Киів, аби посунути справу. Зараз я служу в Петербурзі.

«Головатий» друкується і може за тиждень буде готовий. Після того піде брошура «Про сухоти на хворобі» Ваганова, а там буде «Богдан Хмельницький». Поталанило нам на Богданів - дозволено аж три: крім Вашого, - ще Кулішів та I.С. Левицького.

Два дальших томів «Віку» вже в цензурі; єсть ще там три тому «Української бібліотеки» (твори Руданського, Свіцького та Кримського) і кілька добрих народних брошюр. Петербурзьке «Благотв. Общ.» вдається до цензури 3 проханням, аби ему безборонно дозволялися медичні популірні брошюри.

3 глибоким поважаннєм О.Лотоцький.

СПбург. 1901.I. 29. Мойка, 76.» 


\section{Документ №7. Лист О. Лотоцького. 1901 р. С.-Петербург.}

«Щироповажний Михайло Федоровичу.

Посилаю Вам малюнки д.Ждахи, як про се ми умовились.

«Богдан» вже в друкарні, але ледве чи появиться він раніше, як через місяць, бо дуже затягується справа $з$ малюнками. Хотілося б дуже дати хоч 10 малюнків і для того переглянув я всі периодичні і ілюстровані видання російські, думаючи там знайти щось відповідне, та дарма. Зараз маємо вже готовий портрет Богдана і памятник ему; ждемо 3 Киіва малюнки Переяславської ради та Суботівської церкви - і не тому здається, буде край, бо більш нічого здобуть не можна. Чи не маєте Ви чого такого? Чи не придатний би був який 3 малюнків до «Чорної ради»? Коли дасте яку раду, то я просив би не одмовити скорою відповіддю.

Посилаємо д. Ждасі его проект малюнка для обкладинки з нашими увагами, як він хотів того. Коли б він за два тижні прислав свій малюнок, то та обкладинка встигла б ще захопити «Богдана», що було б дуже бажано.

Зараз маємо готових три брошури, але затягується їх випуск через ріжні причини. «Оповід. про Т.Шевченка» затягується теж через малюнки; на сім тижні його випускаймо. «Виноград» та «Сухоти на худобі» давно готові, але ждуть санкції Міністерства хліборобства. В наборі і - «Виговщина». Друкарня не може зараз стільки рукописів держать в наборі - через те треба буде «Богдана» одддать у другу друкарню.

Я Вам маю послати тих 50 р., що взяв було з книгарні «Київ. Старини», за третій том О.Я.К., сподіваючися, що небіжчик О.Я.Кониський видав третій том цілком за свої кошти. Переписавши для цензури 4 і 5 дальші томи, я витратив сі гроші і прошу Вас, чи не згодилися б ви взяти належні Вам 100 р. за третий том з цих грошей, що будуть в книгарні від продажі сего решту - після 1 січня 1901 р. Дуже прошу мене сповістити. Був би вдячен, коли б ви додали ще до речи чи не потеланило Вам здобути яку посаду для бідолахи Чернявського.

З глибоким побажаннєм О.Лотоцький».

\section{Документ №8. Лист Г. Мачтета. 1896 р. Зарайськ.}

«г. Зарайск. 12 марта 1896 г. Рязанск. г.

Очень благодарю редакцию за доброе, ласковое слово, радуюсь, что группе хороших людей удалось взять в свои руки хотя бы маленький журнал и обещаю непременно прислать что нибудь в этом же году. За последнее прошу выслать мне журнал «По суше и морю» (г.Зарайск, Рязанск. губ. мне) и в особенности прошу, как услуги, за которую буду крайне признателен, достать для меня Шевченковский номер галицкой «Зори».

С искренним признанием и пожеланием всего хорошего.

ОННБ. РКП 28/5. - Арк 76, 113.

Григорий Мачтет»

\section{Документ №9. Лист Д. Мордовцева. 1896 р. Кисловодськ.}

«Кисловодск, 5-VII-96

Між морями гори хмарою повиті, Засіяні горем, кровію политі...

Щире шановний добродію-земляче!

Ви вже знаєте «Складку», що спорудив К.А.Біліновський, й привітали вже цю українську «ластівку» (не «метелика», а цілу «ластівочку») добрим словом. Спасибі за ласку, а пишуть до мене - що Ви, добродіє, й мене старого привітали в часописі - «По морю й суше».

Тепер д. Білило пише до мене про свою сварку з Л.О.Григоровим і благає, щоб і я був радником у цій сварці та й Вас вельми запрошує про те. Порадьте, добродію, Григорову - не доводить бідної «ластівочки» до суду, до гласности, до скандалу, щоб у «заплаканої матері» від сорому щічки не загорілись. Д.Білило просе, щоб і лист до Григорова (копію) я заслав до 
Вас. Засилаю. Зробіть, що зможете: Ваше слово послухається, бо воно буде словом щирого земляка. неньки.

Бувайте здорові на користь «заплаканої матері», бо Ви - не одцурались од старої

А я оце за - весну й літо написав (Ваша рада) історичний роман «Дві долі», - таки чималенький - аркушів 320 й більше друку.

Щиро прихильний Данило Мордовець».

ОННБ. РКП 28/5. - Арк 134.

\section{Документ №10. Лист В. Скидана. 1896 р. Катеринодар.}

Многоуважаемый Михаил Федорович!

«Екатеринодар 9 июля 96 г.

На Ваше письмо от 22 июня, собрав всякие справки от лиц вполне компетентных, могу ответить следующее. Портрет Головатого два года тому назад искали для книжки «Кубанское казачье войско» (изд. 1888 г.) и нигде не могли найти. Изъездили хутора, обыскали церковь Головатого в Тамани - и напрасно. Напали на след у наследников генеральши Зинченко, но пока этот след ни к чему не привел. Советуют искать в тех церквях, где он был ктитором, до переселения, между прочим в Новомосковске.

Поночевный - ученик Вл.Б.Антоновича (хорошо ему известный) говорит, что песнь «чорна хмара наступає» приписуют Головатому. И за тем его те две песни, о которых Вы пишите. Больше ничего не известно. Тот же Поночевский сообщает, что у Вл.Б он видел некий сборник статей, между которыми есть статья о Головатом, где прекрасно описана наружность Головатого. Статья больше анекдотическая. Затем в записках Одесского Общества истории есть несколько статей о военных подвигах, между прочим характерный отзыв Головатого о священнике Ковалевском. В Таманской церкви много подарков Головатого - блюдо, евангелие и пр.

У Мовы не был и думаю, что всего лучше будет, если Вы сами ему напишите. О Вашей работе я ему подробно рассказывал при первом с ним свидании. После того у него не был, встречаюсь случайно. Вот все, что могу сообщить по интересующим Вас вопросам. Теперь о своих делах. Прилагаемые деньги прошу передать Лаон А. как мой долг за прошлый год. Прошу у него извинения за неаккуратность. Осенью еще пришлю. Просите его выслать мне отчет о ночлежных приютах. Весьма обяжете.

Предполагал я, как Вам писал, устроить здесь книжную лавочку на имя сестры. Но это дело разстроилось, по семейным обстоятельствам. Продолжаю мечтать если не о книжной торговле в далеком будущем то хоть о комиссии. Спрос на книжки есть, а предложения мало. Как вы об этом думаете? С какой уступкой можно будет получать из Киева и Одессы? При первых свободных 100 руб, выпишу, если столкуюсь с местными книготорговцами. Перетолкуйте, при случае, с кем нужно по этому предмету. Поклон всему Вашему семейству и всем общим знакомым.

Жму Вашу руку Вл. Скидан».

ОННБ. РКП 28/6. - Арк $61-62$.

Документ №11. Лист П. Стебницького. 1900 р. С.-Петербург.

«15 жовтня $1900 \mathrm{p}$.

Вельми шановний Михайло Федоровичу.

Поперед усього порадую Вас доброю звісткою: сьогодні взяв я з цензури «Антона Головатого» дозволеного до друку. Хвалить Бога - якось проскочив. Отже тепер кажіть що 3 цим робити: чи починать друкувати тут, чи Ви хочете самі цього діла доглянути $\mathrm{i}$ видрукувати, і взагалі, як Ви думаєте поставити матеріальну сторону видання. Коли можно, не баріться, будь-ласка, з відповіддю, бо у нас поки що це одна готова рукопис, що вже можно друкувати, - а то або в цензурі, або ще не подані. 
Зараз же подам Богдана, побачим як він пройде.

Подане оповідання Кониського - «Смерть предателя» (що у III томі) прокляті цензори направили в духовну цензуру, а там зараз же поставили заборону, звичайно без всяких мотивів. 3 цього вивожу, що така ж доля буде і Вашого Кирила з Мефодієм; через те поки що не буду його подавати - нехай виясниця.

Чом не присилаєте нам обіцяних 170 карб. 3 офіціяльною бумагою? Шліть на ймення голо - Д.Л.Морд. (Столярний пер. 6).

Давайте рукописів коли єсть готові.

Писала Кулішиха, що малюнки до «Чорної Ради» вже вийшли 3 цензури. Я надзвичайно радий. Присилайте ж нам примірників 15 або 20 простих і не менш як 103 малюнками. [...]

Вже більше місяця як я вернувся в Петербург, та не міг до Вас обізватись; не пощастило мені в подорожі: захопив десь аж за кордоном натуральну віспу (лиш дуже легеньку), приїхав хворий і мусив ще кілька часу вилежати в шпиталю. Оце тижнів до два як приступив до своїх справ та потроху даю лад тому, що набралося за літо.

Бувайте здоровеньки; низько кланяюся Вам і Вашій родині. Пишіть же, будь ласка. Що нового? Чи балакали з Мах.?

Щиро приязний і шануючий Вас П.Стебницький».

ОННБ. РКП 28/7. - Арк $16-17$.

Документ №12. Лист В. Шамрая. 1902 р. Катеринодар.

«Милостивый Государь Михаил Федорович.

Узнав, что Вы работаете в одной со мной области литературного труда (библиография), с удовольствием посылаю Вам по экземпляру печатных своих последних трудов и льщу себя надеждою, что вы не откажете поделиться со мною и своими.

С истинным почтением Ваш покорнейший слуга В.Шамрай.

20/II - 1902

Екатеринодар. Кубанское Областное Правление».

\section{Документ № 13. Лист К. Шрама К. [1904 р.] Тирасполь.}

«Тирасполь 22 IX

Любий усім нам Михайло Федорович!

Тильки що прочитав довгу, дуже цікаву і доладу написану статтю про те, що діялось в Москві на з'їзді земців і горожан. Говорили про самостайне життя різних народів - поляків, кавказців, фінів. Радісно відкликались на надію Польши, Кавказа, Финляндіи мати «у своїй землі свою волю и правду»; навіть говорили про бурят...

А де ж ми були? Що робили наші люде? Не вже сиділи по закутках та чекали, може і про нас згадають ї нам щось дадуть? Один тільки Максим Ковалевський щось натякнув про те, що Украінські де-які землі боролись за автономне життя майже з II віку, та й замовк. Боже, Боже, не вже 200 літне духовне безхлібе і безліте нас так знівечили, що в такий случний стан, який тепер переживаем, серед нас не нашлось ні одного чоловіка що поіхав би в Москву і одстояв наші чоловічі і національні права перед репрезентантами усіеї Росіі. Які ж ми несчасні раби.... Простіть, що так пишу, не я пишу: у мене все болить од думки, що не стало у нас волі і розуму за себе говорить там, де треба».

\section{Документ № 14. Лист Д. Яворницького. 1899 р. Москва.} «18 IV/22 99

Москва, Зарядье, Кривой пер., д. Бахрушина

Вельми поважний Михайло Хведорович!

Дуже дякую Вас за Ваш щирый та прихильний до мене лыст! А я таки прызнаюсь Вам, подумав, що добри люде цураются мене, и гирко-гирко зробылось у мене на души... «За що и як»? думаю соби. Нехай у мене там талану историка нема, так хиба як за це уже и 
зневажити чоловика? Та як бы ж там хто другый мене зневажыв, а то ж такы КомаровУманець? Мабуть, багато чого у мене непрыемного, що люде цураются мене... Так от так, голубчику, спасыби Вам сердешне за Ваш лист!...

Надсилаю Вам мою рукопис «Максым Мыкытович Витряк». Те що таменькы розскажетця, було як есть так $з$ чоловиком, и тут моего твору дуже мало. Одно тильки й скачу Вам, що ци лысты розмов, яки есть у рукописи, запысаны бильш усего коло могыл, як от то я у литку копаю их та веду балачку 3 копачамы. Есть таки оброты, що мени и не прынадать таких; то Вы не дивуйтеся тому; есть и слова таки, якых зроду вику до моих мандривок по Запорожжу не чував. Одначе, Вы, голубе мій, вычытайте усе с особшою увагою, видчеркнить те усе, що Вас здается негаразд, оливцем (а не пером), розсмакуйте мого Витряка и всих его сынов добре, подумайте над там, чи вирно в мене списана природа, и скажить мени напослыдок правду, щыру, свыту правду. Памьятайте те, що як мій твир некчемный, то я тым й скинчу, - бильш такого не пысатыму; а як що Вы прызнаете его добрым, то я ще попробую себе на историчний хроници добы кошового Сирка. Самому мени багато чого не подобаеться, и я уже кильки разив рвав мого «Витряка» на шматки, а от то мисяцив за тры, як перепысав його так и покинув не чытаючы, - може чи есть и прогалыны. Бильш усього не подобаетця мени та глава, де Павлусь Витряченко (штундыста) выявляе злодійства нашых попив (XVII), в ній нема художества, а зате есть щыра правда, и через це мени шкода ый выкынуты. Кажить же мени усе, и я послухаюсь Вас, яко знатока украинскои мови и творчества.

Серцем Ваш Д.Эварницкий.

Першого мая я выіду до Петрограда, и як що Вы до того чысла не встыгнете вычытаты мою рукопись, то надишлить ій такій адреси: Его Прев-у Гофмейстру Высочайшего Двора Георгию Петровичу Алексееву. Угол Сергиевской ул. И Воскресенского просп., д. Зейфарта для передачи Д.И.Эвар-у».

Джерела та література:

1. Одеська національна наукова бібліотека (далі ОННБ). РКП 28/1.

2. ОННБ. РКП 28/2.

3. ОННБ. РКП 28/5.

4. ОННБ. РКП 28/6.

5. ОННБ. РКП 28/8.

6. ОННБ. РКП 28/10.

References:

1. Odeska natsionalna naukova biblioteka (next ONNB). RKP 28/1.

2. ONNB. RKP 28/2.

3. ONNB. RKP $28 / 5$.

4. ONNB. RKP 28/6.

5. ONNB. RKP 28/8.

6. ONNB. RKP 28/10.

Отримано: 05.12.2020 p. 